\title{
Türk Yapım Şirketlerinin Görsel Kimlik Bağlamında İncelenmesi: BKM Örneği
}

\author{
Mesut Aytekin (Dr. Öğr. Üyesi) \\ (iD) İstanbul Üniversitesi İletişim Fakültesi \\ mesutaytekin@gmail.com \\ Özer Silsüpür (Öğr. Gör. Dr.) \\ (iD) Trabzon Üniversitesi İletişim Fakültesi \\ ozer.silsupur@gmail.com \\ Başvuru Tarihi: 27.07.2021 \\ Yayına Kabul Tarihi: 05.10.2021 \\ Yayınlanma Tarihi: 28.10.2021 \\ https://doi.org/10.17680/erciyesiletisim.974901 \\ Öz
}

Görsel kimlik, kurumların tanınması ve farklılaşması için çeşitli tasarım öğelerinin bir bütün halinde değerlendirilmesi gereken çalışmalardır ve logo da bu öğelerden biridir. Logo, kurumların diğer kurumlardan görsel açıdan ayırt edilmesine yarayan, kurumu hedef kitleye görsel olarak tanıtan ve hedef kitleyle duygusal bağ kurulmasına yardımcı olan önemli bir görsel kimlik aracıdır. Logolar, markaların güçlü oldukları yönleri vurgulayan ve markaların tanınmasında etkili olan özel tasarım ürünleridir. Bu çalışmada, Türkiye'de tiyatro ve sinema alanında birçok projenin gerçekleşmesine, sanatın-kültürel hayatın gelişmesine katkı sağlayan, sinema alanında son yıllarda en çok film üreten ve hasılat elde eden yapım şirketi olan Beşiktaş Kültür Merkezi'nin (BKM) kurumsal logosu, görsel kimlik açısından 01.05.2021-15.05.2021 tarihleri arasında analiz edilmiş, BKM’nin logosunu nasıl kullandığı, şekillendirdiği, logonun çağrışımları ve markaya katkısı logonun temel öğeleri bağlamında değerlendirilmiştir. Araştırma sonunda BKM logosunun, gerek tipografi gerek renk kullanımı ve gerek uygulama alanları bağlamında üzerinde düşünülmüş profesyonel bir çalışma ürünü olduğu saptanmıştır. BKM logosu görsel kimliği tamamlayıcı, markayı ön plana çıkartan ve her yerde temsil edebilecek bir tasarıma sahiptir. BKM logosu, Türk yapım şirketlerinin görsel kimlik çalışmalarında örnek alması gereken bir kurumsal kimlik materyali olarak dikkat çekmekte, görsel temsiliyet bağlamında sorunlar yaşayan yapım şirketleri için önemli çözüm önerileri sunmaktadır.

Anahtar Kelimeler: İletişim, Türk Sineması, Yapım Şirketleri, Görsel Kimlik, Logo, BKM. 


\title{
Examining Turkish Production Companies in the Context of Visual Identity: The Example of BKM
}

Mesut Aytekin (Asst. Prof. Dr.)

İstanbul University Faculty of Communication

mesutaytekin@gmail.com

Özer Silsüpür (Lect. Ph.D.)

iD Trabzon University Faculty of Communication ozer.silsupur@gmail.com

Date Received: 27.07.2021

Date Accepted: 05.10.2021

Date Published: 28.10.2021

https://doi.org/10.17680/erciyesiletisim.974901

\begin{abstract}
Visual identity needs to be evaluated as whole for the recognition and differentiation of institutions, and the logo is one of these elements. The logo of institutions from other institutions serve to distinguish visually, corporate audience visually promote and audience is a tool helping visual identity to establish emotional bond. Logos are effective custom products that emphasize recognition and direction of strong brands. Study reveals the company contributes to realization of projects in the fields of theater, cinema, development of art, cultural life. Logo of Beşiktaş Cultural Center (BKM)'s visual identity, a production company that produced and earned the most movies in cinema in recent years, was analyzed between 01.05.2021/15.05.2021. How BKM used and shaped its logo, the associations of the logo and its contribution to the brand, basic elements of logo were evaluated. Finally, BKM's logo is a professional product that is within typography, color use and application areas. BKM logo has design that complements visual identity, highlights brand and can represent it everywhere. Also, draws attention as a corporate identity material that Turkish production companies should take as an example and offers important solutions for production companies having problems with visual representation.
\end{abstract}

Keywords: Communication, Turkish Cinema, Production Companies, Visual Identity, Logo, BKM. 


\section{Giriş}

Kurumsal kimlik, kurumların, hedef kitlelerinin gözünde nasıl farklılaştığını ve rakipleri karşısında kendilerini nasıl konumlandırdığını anlatan görsel ve görsel olmayan çalışmalarıdır (Silsüpür, 2015, s. 264). Kurumların birbirlerinden görsel öğelerin birleşimiyle farklılaşmasını sağlayan görsel kimlik, hedef kitlelere kurumun tasarım çalışmalarını yansıtmakta (Bayçu, 2012a, s. 48) ve kurumun kendisini tanıtmasına, hedef kitlelerin de kuruma dikkatinin çekilmesine fayda sağlamaktadır (Bouchet, 2000, s. 2). Bu sebeple kurumlar, hedef kitle tarafından bilinmek ve kurumsal imaj olușturmak için görsel kimlik çalışmalarına önem vermekte (Türkoğlu, 2008, s. 18) ve de kurumsal amaçlarına ulaşmak, rakiplerinden farklılaşmak, hedef kitleleri etkilemek ve hedef kitle algılarında olumlu yer edinmek için görsel kimlik çalışmalarında bulunmaktadırlar.

Kurumların kendilerini görsel olarak ifade etmesi şeklinde tanımlanan görsel kimlik (Bakan, 2011, s. 291); kurum isminin yazılışını, kurumu çağrıștıran ve kuruma ait her türlü araç ve gereçlerde kullanılan rengi, yazı karakterini, sembollerin tasarımını kapsamaktadır (Peltekoğlu, 2004, s. 376). Görselliğin etkileyiciliği ve dikkat çekiciliği düşünüldüğünde, kurumların logo tasarımında renk, şekil, yazı karakteri, tipografi gibi unsurları bir bütünlük içinde kullanmaları, kurumun yapısına ve kişiliğine uygun görsel kimlik bileşenleriyle logolarını tasarlamaları gerekmektedir. Dolayısıyla kurumlar hedef ve amaçlarına ulaşmak için görsel kimliğe ait tasarımları baştan düşünüp, bir ahenk ve uyum içinde tasarlamalı ve hedef kitleleri duygusal açıdan etkileyip olumlu kurumsal imaj oluşturmalıdırlar. Bu bağlamda çalışmada, BKM’nin kurumsal logosu incelenmiş ve görsel kimliğe ait unsurların ne derece göz önünde bulundurulup, görsel kimliğe ait tasarımların bir bütün içinde ele alınıp alınmadığı analiz edilmiştir.

\section{Sinemada Yapım ve Yapımcılık}

Sinema, uzun ve zorlu çalışma koşulları içeren değerler zinciri içerisinde kolektif bir işbirliği gerektiren, Giovanni Scognamillo'nun ifadesiyle devasa bir endüstridir. Yapım, sinemanın tüm değerler zinciri içerisinde özellikle film üretim sürecini kapsayan aşamalarına verilen addır. Yapım genel anlamda Yapım Öncesi (Pre-Prodüksiyon), Yapım (Prodüksiyon), Yapım Sonrası (Post-Prodüksiyon) aşamalarını kapsar. Kısaca yapım, filmin fikir aşamasından son gösterim aşamasına kadar olan çalışmaları için kullanılan bir kavramdır. Bu süreçlerden doğrudan ve dolaylı olarak pek çok insan ve sektör etkilenmektedir.

Sinema filmlerinin yapımını ise yapımcı adı verilen sinema emekçisi gerçekleştirmektedir. Değerler zincirini yöneten, tüm sorumlulukları alan kişi yapımcıdır. Başka bir ifadeyle teorik olarak yapımcı, sinema ve dizi projelerinde, projenin tüm maddi ve manevi süreçlerinin tek hâkimidir (Meyfilm, 2017). Yapımcının görevlerini şu şekilde özetlemek mümkündür:

"Film yapımcıları, dünya çapında fikir ve hikâye geliştirirler. Bu süreçte, gereken yasal izinleri sağlamak, güvenli finans kaynakları yaratmak, yazar, yönetmen ve oyuncuları bulmak, teknik ekibi kurmak ve diğer yaratıcı süreçleri takip etmekten sorumlu kişilerdir" (Sinema Eseri Yapımcıları Meslek Birliği, 2021).

Film yapımcıları, film süreçlerinin dağıtım ve gösterimde dâhil hepsinde yer alarak filmin başarıya ulaşmasında etkin bir role sahiptirler. "Yapımcılar, geliștirme, finansman, yapım öncesi faaliyetler, ana fotoğrafçıllı, post prodüksiyon faaliyetleri ile satış ve pazarlama dahil 
olmak üzere filmin yaratılışının tüm aşamalarında yer alırlar" (Internatioal Federation of Film Producers Associations, 2010).

Yapımcılar genel olarak sektörde sadece bütçe bulan kişi olarak algılansa da aslında çok farklı çalışmaları gerçekleştirmektedirler. "Yapımcı, filmin sanatsal ve finansal hedefleri arasında bir denge görevi görmektedir" (Cima, 2021). Sinema endüstrisinde yapımcllı̆̆ın farklı türleri, farklı çalışma şekilleri vardır. Genel olarak yapımcılar, sadece işin maddi ve bürokrasi kısmıyla ilgilenen yapımcılar, uygulayıcı/yürütücü yapımcı ve yaratıcı yapımcı olmak üzere üç farklı şekilde faaliyet gösterilmektedirler. Uygulayıcı/Yürütücü yapımcı, filmin başarılı bir şekilde çekilmesini sağlayan kişidir. Bütçenin dengeli bir şekilde harcanmasını sağlayarak yaratıcı ekibin ihtiyaçlarını karşılar.

"Yürütücü yapımcl, filmin sadece çekimle ilgili süreçlerinde görev alan, sahada operasyonu yürüten, öte yandan filmin finansmanıyla ilgili sorumluluğu bulunmayan, mevcut çekim planına ve bütçeye uygun bir şekilde projeyi yürüten kişidir. Yürütücü yapımcılar filmin herhangi bir mali hakkına sahip olmazlar, ücret karşılı̆̆ı çalışırlar" (Sinema Eseri Yapımcıları Meslek Birliği, 2021).

Nadir Öperli yaratıcı yapımcılığın, yaratıcı iş birliği içermesi ve içeriğe katkıda bulunmayı gerektirdiğini ifade etmektedir (Şatana \& Yücesoy, 2018). Bu anlamda yaratıcı yapımcı, filmin fikir aşamasında, senaryonun yazımında ve geliştirilmesinde, genel konseptin oluşturulmasında, mekânların, dekorların ve kostümlerin belirlenip ortaya çıkarılmasında bizzat yer alır, düșüncelerini aktarır, katkı sunar. Bu yüzden yaratıcı yapımcının, zengin bir kültür birikimine sahip, vizyoner, kreatif bir kişi olması gerekmektedir.

Yapımcl, organize bir iş süreci yürütebilmek için şirket bünyesinde faaliyet göstermektedir. Şirket başka bir şahsa ait olabileceği gibi genel olarak Türk Sineması'nda olduğu gibi yapımcıya da ait olabilmektedir. Yapım Şirketleri, sinemanın başından beri var olmuşlardır. Kanuni bir zorunluluk olan şirket kurma nedeniyle hayata geçen yapım şirketleri zaman için de kurumsallaşmalarını tamamlamış, iş bölümlerini başarılı bir şekilde gerçekleştirmişlerdir.

"Özellikle belgesel filmden kurmacaya geçiş yapılması, filmlerin süresinin uzaması, mekânların çeşitlenmesi, kameranın hareket kabiliyetinin artması, efektif tasarımların gelişmesi, zengin dekor ve oyuncu kadrosunun oluşturulması yapım masraflarının artmasına sebep olmuş, grup çalışmasını ve iş bölümünü mümkün kılan belirli birimleri kendi bünyesinde toplayan yapım şirketlerinin kurulması zorunlu hale gelmiştir" (Şentürk, Gülçur, \& Eken, 2017).

Büyük bütçelerin harcandığı, birçok kişinin görev aldığı yapım süreçleri profesyonel bir yönetim gerektirmektedir. Sinemada hem insan hem de zaman yönetimi büyük önem taşımaktadır.

Sinemanın gelişimine paralel bir şekilde yapım şirketleri de gelişmiştir. Çağın şartlarına göre teknolojinin de etkisi ile dönüşüm ve değişimler geçirmişlerdir. Her geçen gün büyüyen sinema endüstrisinin sorunlarına çözüm bulmuşlar, filmlerin seyirci ile buluşmasında önemli rol oynamışlardır. Yine ülkelerin gelişmesinde, ekonomiye katkıda bulunulmasında, istihdamda, kültürel ve sanatsal üretim bağlamında önemli katkılar sağlamışlardır. Sinemanın yüksek kazanç getirebilen bir sektör olması, pek çok şirketin kurulmasına da sebep olmuştur ancak pek çok etkene bağlı olan sinema sektörü mükemmel iş birlikleri ve çok ciddi planlama gerektiren ve her aşamasında profesyonel 
bir yaklaşım bekleyen bir endüstri olduğundan aynı zamanda pek çok şirketinde battığı bir sektördür.

Yapım şirketleri, sinema endüstrisinin sağlıklı bir şekilde işleyebilmesi için gerekli kurumlardır. Hem film üretilebilmesi hem çalışanların haklarının ödenmesi ve korunması ancak hukuka uygun, düzgün ve profesyonelce çalışan yapım şirketleriyle mümkündür.

\section{Türk Sineması'nda Yapımcılık ve Yapım Şirketleri}

Türk Sineması'nda film üretimi çok geç başlamıştır. Sinemanın ilk gösteriminin yapıldığı yıl 1986 olmasına rağmen ilk film 1905 yılında Manaki Kardeşler tarafından çekilmiştir. Makedonya topraklarında fotoğrafçılık ile uğraşan Milton ve Manaki kardeşlerin, Büyükanne Despina ve Yün Eğiren Kadınlar adındaki filmleri Türk Sineması'nın ilk filmidir.

Dönemin getirdiği siyasal, sosyal ve ekonomik sıkıntılar, Türk Sineması'nın daha çok yabancılar tarafından icra edilen bir ișkolu olarak gelișmesini sağlamıștır. Bireysel girişimler ve faaliyetler şeklinde ilerleyen Türk Sineması, çeşitli cemiyetlerin sinema faaliyetleri, haber filmi çekimleri ile ilk yıllarında çok yavaş ilerlemiştir. Daha çok ithal edilen filmlerin gösteriminin yapıldığı üretimden ziyade tüketimin yapıldığı bir sektör görünümü vardır.

Balkan Savaşları, I. Dünya Savaşı sinema çalışmalarını durma noktasına getirmiştir. Hem siyasi hem de ekonomik sıkıntılar, sosyal yaşamın ertelenmesine neden olmuştur. Bu yıllarda Türk Sineması daha çok propaganda faaliyetleri için kullanılmıştır. Özellikle cemiyetler, cephelerde çekimler yapmış, halka umut veren görüntüler elde etmeye çalışmıştır. 1914 yılında Fuat Uzkınay tarafından çekilen Ayestefanos Abidesi'nin Yıkılışı filmi de bir propaganda film olarak çekilmiş ve İstanbul'daki sinemalarda gösterilmiştir. 1915 yılında bir yapım şirketi gibi faaliyet gösteren Merkez Ordu Sinema Dairesi (MOSD) kurulmuştur. Enver Paşa'nın emri ile ordu bünyesinde kurulan MOSD, silah kullanımlarını gösteren, cepheden filmler çekmiş; dönemin önemli olaylarını kayda almıştır. Bu görüntülerin gösterimleri de yapılmıștır.

I. Dünya Savaşı sonrası işgale uğrayan Osmanlı topraklarında Malul Gaziler Heyeti, yapım şirketi gibi haber filmleri yanında Türk Sineması'nın ilk kurmaca filmleri olan Pençe ve Casus filmlerinin çekilmesini sağlamıştır. 1917 yılında Sedat Simavi tarafından çekilen bu filmleri, Bican Efendi serileri, Mürebbiye (1919) gibi filmler takip etmiştir.

Ordunun ve sivil toplum kuruluşlarının (STK) çabaları ile sürdürülen sinema çalışmaları, 1922 yılında Türk Sineması'nın ilk özel yapım şirketi Kemal Film'in kurulmasıyla tamamen sivil bir kimliğe bürünmüștür. Önemli haber filmlerine imza atan Kemal film, Muhsin Ertuğrul yönetiminde kurmaca filmler de çekmiştir. 1928 yılında Türk Sineması'nın ikinci özel yapım şirketi İpek Film kurulmuştur. Tiyatrocular Dönemi adı verilen bu dönemde çok az film üretilebilmiştir. 1930'ların ikinci yarısı ile birlikte Ha-Ka film gibi yeni yapım şirketleri de Türk Sineması'nda faaliyet göstermeye başlamıştır. 1940’lar ile birlikte yurt dışından gelen Türk girişimciler, Türk Sineması'ndaki tiyatro egemenliğine son vermişlerdir. Zengin'de (2016, s. 126), Türk Sineması'nın Geçiş Dönemi olan 1939-1950 yılları arasında, Türk Sineması'nın üretim, dağıtım ve gösterim aşamalarında sektörleşme çabalarının olduğunu ifade etmektedir.

Yönetim sisteminde çok partili hayata geçiş, demokratik ve ekonomik atılımlar 1950'lere damgasını vurmuştur. Devletin vergi teşvikiyle birlikte 1950’ler Türk Sineması için yeni 
bir sinema anlayıșının doğduğu yıllar olmuştur. Ömer Lütfi Akad, Metin Erksan, Atıf Yılmaz, Memduh Ün ve Osman F. Seden gibi Türk Sineması'nın önemli yönetmenleri ilk filmlerini çekmiştir. Türk sineması tiyatro etkisinden kurtularak gerek sinematografik gerekse öykü anlamında başarılı çalışmalara imza atmıştır. Bu yıllar Türk Sineması'nda “Sinemacılar Dönemi”nin başladığı yıllardır.

Sinemaya artan ilgi yeni yapım şirketlerinin kurulmasının da önünü açmıştır. Ancak yeterli sermayesi olmayan bu yapım şirketleri film çekebilmek için daha çok ortaklık yolunu tercih etmişlerdir. Zaman içerisinde artan izleyici sayısı, yükselen gișe hasılatları, yeni sinema salonlarının açılması Türk Sineması'nı hareketlendirmiştir. Yapım şirketleri, filmlerini, Anadolu'da pursantaj adı verilen bir yöntem ile göstermeye çalışmıştır.

1960'lı yıllar Yeşilçam’ın altın yılları olarak adlandırılmaktadır. Seri halde, farklı türlerde seyirciyi sinemaya çeken birçok film üretilmiştir. Yıldız oyuncuların seyircileri derinden etkilediği, sinemanın aile eğlencesi olarak ön plana çıktığı yıllardır. Buna karşın yapım şirketleri, kazandıkları parayı etkin kullanmadığından bütçe bulmak için farklı arayışlara girmişlerdir. Abisel (1994, s. 99), önemli bir firsat sunan bu dönemi, yapımcıların değerlendiremediğini ifade ederek, bu dönemde yapımcılığın ciddi ve planlı bir girișim olarak gerçekleşmediğinin altını çizmektedir. Yapım şirketleri, çözümü Anadolu'da gittikçe güçlenen bölge işletmelerinde bulmuştur. Bütçeyi tamamlayamayan yapımcılar, bölge işletmelerine, filmin bölge işletme haklarını asgarisi ve azamîsi hemen hemen belli nakdî değerlerdeki bonolar karşılığında satmakta ve kiralamaktadırlar (Gökmen, 1973, s. 51). Seyirciyi yakından takip eden bölge işletmeleri, yıllık değerlendirmeleri neticesinde film siparişleri vermeye, bu filmler için ödemeler yapmaya başlamışlardır. Bölge işletmeciliği adı verilen bu sistem ile Türkiye, Adana, Ankara, İstanbul, İzmir, Samsun ve Zonguldak olmak üzere altı bölgeye ayrılmıştır. Bölge işletmecileri, bütçe güçleri ile istedikleri senaryoları çektirip istedikleri oyuncuları filmlerde oynatarak Türk Sineması'na yön vermişlerdir. 1960 yılında başlayan bu sistem 1975 yılında TRT ile birlikte televizyonun Anadolu'da yaygınlaşmasıyla etkisini yitirmeye başlamıştır (Çam, 2018, s. 19).

1980 darbesi ile sorunlu yıllar geçiren Türk Sineması, zoraki bir değişimin içine girmiştir. Değișen dünya ve ülke şartları, siyasal baskılar, politik ve ekonomik gelişmeler, Yeşilçam anlayışını sona erdirmiştir (Aytekin, 2017, s. 74). Televizyon ile birlikte videonun ortaya çıkışı, film üretiminin bu sektörlere doğru yönelmesine yol açmıştır.

Yabancı film şirketlerinin Türkiye'de faaliyet göstermesinin önünün açılması 1990’lı yıllara damgasını vurmuştur. Özellikle büyük Amerikan şirketlerinin baskın dağıtım politikaları film üretim ve gösterim sürecini etkilemiștir (Aytekin, 2017, s. 74). Özel televizyonların da açılması ile birlikte sinema seyircisi sinemalardan uzaklaşmıştır. Yapım şirketlerinin birçoğu ya kapanmak ya da televizyon, reklam gibi farklı sektörlere içerik üretmek durumunda kalmıştır. Mevcut yapım şirketleri ise Türkiye'nin 1990 yılında üye olduğu Eurimages ve 1991 yılında başlayan devlet desteği ile filmlerini finanse etmeye çalışmıştır. Bu yıllarda televizyonun da sinemaya film üretimi bağlamında olumlu etkisi olmuş, sektör sponsorluk kavramı ile tanışmıştır.

Eşkıya, İstanbul Kanatlarımın Altında gibi filmlerin büyük başarı yakalayıp seyirci çekmesi, Türk Sineması'nda yeni bir dönemi başlatmıştır. 2000'li yıllar yönetmen-yapımcıların ortaya çıktığı, Türk Sineması'nın ticari ve bağımsız olarak adlandırılan iki üretim şeklinde ilerleyen bir yapıda film üretimine devam ettiği yıllar olmuştur. Dijitalleşme ile birlikte teknolojik gelişmelere uyum sağlayan Türk Sineması hem film üretimi hem de gösterim anlamında büyük bir değişim geçirmiştir. Artık film çekmek daha kolay ve daha ucuz bir 
hale gelmiş, sinema salonlarının hizmet kalitesi artmıştır. Filmler sinema salonları dışında VCD ve DVD ile televizyon satışlarından da gelir elde etmeye başlamıştır.

Alışveriş merkezleriyle (AVM) birlikte küçük ama çok salonlu sinema anlayıșı tüm ülkeye yayılmıştır. Genç yönetmenler başarılı projeleri ile yurt içi ve yurt dışı festivallerden ödüller almaya başlamıştır. Ses getiren bu başarılar, 2004 yılında çıkarılan sinema filmlerinin sınıflandırılması ve değerlendirilmesi kanunuyla birlikte devletin sinemaya desteğini artırmıştır. Tecrübe kazanan Türk Sineması Eurimages'ten daha fazla bütçe almaya, yabancı ortaklar ile projeler geliștirmeye, sponsorluk ve reklam çalışmalarına önem vermeye, yerli ve yabancı film fonlarına başvurmaya başlamıştır (Erkılıç, 2009, s. 147). Özellikle bağımsız yapım şirketleri bu şekilde karma finansman kaynakları ile başarılı filmler üretir hale gelmiştir. Ticari film üreten yapım şirketleri daha çok sponsor ve devlet destekleri almış, kendi sermayeleriyle bütçe oluşturmaya başlamıştır. Televizyonların ön alımları ve ortaklıkları ile birlikte festival ve yarıșmaların destekleri de Türk Sineması'na önemli katkılar sunmuștur. Bu olumlu gelişmeler hem seyirci hem de hasılat sayılarına yansımıştır. Türk Sineması Avrupa'nın en çok yerli film izlenen endüstrisi olmuştur. Film üretimi yıllık 180'ni aşan bir sayıya ulaşmıștır. Ancak endüstrinin sağlam zemine oturmayan yapısı, dağıtım ve gösterim aşamasında "mısır savaşları" adı altında gerçekleşen krizle sarsılmış, devamında küresel COVID-19 salgınıyla Türk sinema endüstrisi durma noktasına gelmiştir (Aytekin, 2020, s. 73). Ürettikleri filmleri gösteremeyen, yeni filmler çekemeyen Türk Sineması çok büyük zarar görmüştür. Pek çok yapım şirketi kapanma aşamasına gelmiştir. Sektör paydaşları, COVID-19'un etkisinin uzun yıllar Türk Sineması'nda süreceğini öngörmektedirler.

\section{Görsel Kimlik}

Görsel kimlik, kurumları rakiplerinden ayırmakve tanınırlığı sağlamak için gerçekleştirilen görsel tasarım faaliyetleridir (Balmer \& Gray, 2000). Kurumlar, görsel unsurlar aracılığıyla olușturulan kimlik sayesinde, kendilerini rakiplerinden farklılaștırmakta ve kendilerini hatırlatmaktadırlar (Özüpek, 2005, s. 148). Kurumlar vizyonlarına uygun şekilde tasarlayacakları görsel kimliklerle hedef kitlelere kim olduklarını, ne yaptıklarını, nasıl yaptıklarını, nereye ulaşmak istediklerini iletmekte ve bu bilgileri görsel öğelerle yansıtmaktadırlar (Olins, 2002, s. 2). Dolayısıyla kurumlar, görsel kimlik oluștururken kurumun amaçlarını bilmeli ve gelecekte de kurumlarını nerede görmek istediklerini iyi belirlemelidir. Görsel kimlik tasarlanırken çağın ihtiyaçları ve gerekleri iyi bilinmeli ve bu doğrultuda çalışmalar yapılmalıdır.

Görsel kimlik öğeleri olan logo, amblem, renk, slogan, yazı karakteri, tipografi gibi tasarım çalışmaları (Bakan, 2011, s. 291), birbiriyle uyum içinde hazırlanmalıdır. Bir bütünlük içinde oluşturulan görsel kimlik, hedef grupların güvenini kazanmakta ve kabul görmektedir (Köktürk, Yalçın, \& Çobanoğlu, 2008). Görsel kimlik aracılı̆̆ıyla hedef kitlelere verilmek istenilen mesajlar iletilmekte, hedef kitle ve kurum arasinda duygusal bağ oluşturulmaktadır (Aktepe, Baş, \& Tolon, 2009). Bu sebeple görsel kimlik tasarlandıktan sonra sürekli değişime gidilmemeli ve hedef kitlede olumsuz bakış açısı oluşturulmamalıdır.

Görsel kimliğin iyi planlanıp, kurumsal amaçlar doğrultusunda tasarlanması; kurumun hatırlanmasını, ürün ya da hizmetlerin kalitesi hakkında fikir vermesini, kurumların rakiplerinden farklılaşmasını, kurumun görsel öğelerle kendini (yenilikçi, geleneksel, küresel) ifade etmesini sağlamaktadır (Bayçu, 2012b, s. 73). Kurumlar, kendilerini en iyi ifade edecek ve hedef kitlelere kendilerini anlatacak görsel kimlik öğelerini tasarlayarak, 
kurumun algılanmasına, dikkat çekmesine ve bilinirliğinin artmasına imkân vereceklerdir. Dolayısıyla kurumların kendilerini sunma biçimi ve akılda kalıcılığı sağlayan kurum ismi, logo/sembol, renk, slogan, yazı karakteri ve tipografi gibi çalışmaları baştan düşünmeli, kurumun yapısıyla özdeşleşmeli, hafızlarda yer edinmeli ve şekilsel olarak hatırlanmalıdır (Silsüpür, 2020, s. 120-121). Ayrıca bütüncül ele alış ve titiz çalışmalarla tasarlanacak görsel kimlik uygulamaları, hedef kitlelerin kurumlara olan bakış açısını olumlu etkileyecektir.

\section{Görsel Kimlik Öğeleri}

Kurum ismi, kurum rengi, kurumun logosu, kurumun sloganı, kurumun yazı karakteri ve tipografisi görsel kimliğin öğelerini oluşturmaktadır.

\subsection{Kurum İsmi}

Kurumun ayırt edilmesini sağlayan kelime veya kelime öbeklerinden oluşan kurum ismi, görsel kimliğinin oluşturulmasında önemli bir unsurdur (Tuna \& Tuna, 2007). İyi bir kurum ismi, olumlu etki bırakmalı, kulağa hoş gelmeli, hedef grupları etkilemeli, kolay ifade edilmeli ve hatırlanabilir özellikleri taşıması gerekmektedir (Bayçu, 2012b, s. 78).

Ulusal ve uluslararası alanda ürün veya hizmet sağlayan kurumlar isimleriyle hedef kitlelerde güven, kalite, fiyat gibi çağrışımlar yapmaktadır. Kurumlar isim tercih ederken kültürlerarası dil kullanımdan kaynaklı hatalar yapmamalı, anlamlı ve söylenişi kolay isimler tercih etmelidirler. Kurum isimleri, kurucu isimleri ya da soyadlarıyla, işletmeyle, ürünle ya da hizmetle bağlantısı olmayan isimlerle, kısaltmayla, tanım isimleriyle (resmi unvanlarla oluşan isimler), yer ve ülke isimleriyle, mitolojik isimler yoluyla oluşturulmaktadır (Silsüpür, 2020, s. 123-125).

\subsection{Kurum Rengi}

Renkler; dikkat çekme, duygulara etkileme, bir sembole anlam katma yönüyle insanlar üzerinde etki bırakmaktadır (Ak, 1998, s. 111). Hatırlatıcı bir etkiye sahip olan kurum renkleri, hedef kitlelerin, kurumları tanımasında önemli bir iletişim aracı haline gelmiștir (Tuna \& Tuna, 2007). Renkler aracılığıyla hedef grupların, kurumları tanıması kolaylaşmakta ve kurumlar hakkında bilgi sahibi olabilmektedirler (Grimes \& Doole, 1998).

Kurum ismi, logo ve amblemler renkler sayesinde kolaylıkla fark edilmekte (Bottomley \& Doyle, 2006) ve kişilere kurumun yapısı hakkında (hızlı, canlı, enerjik, sakin, gizemli) çıkarım yapmasına olanak sağlamaktadır. Kurumlar güçlü yönlerini vurgulamak, bunlara dikkat çekmek ve kurumun ruhunu kitlelere yansitmak için renklerden yararlanmaktadırlar (Silsüpür, 2020, s. 131). Kurumlar renkler aracılığıyla hem hedef kitlelere mesajlarını iletmekte hem de hedef kitlelerin kurum hakkında bilgi sahibi olmasını sağlamaktadır.

Kurumlar genel olarak siyah, beyaz, gri, turuncu, kırmızı, yeşil, mavi, sarı renklerini kullanarak kurumsal renklerini oluşturmalı, karışık ve ara renkleri ise tercih etmemelidirler. Bu doğrultuda kurumlar yapılarına uygun olarak enerji, heyecan, dikkat çekmek için kırmızı; istikrar ve liderlik için mavi; pozitiflik ve neşe için sarı; saflık için beyaz; lüks için mor; çevrecilik ve sağlık için yeşil renklerini kullanabilirler (Ries \& Ries, 2007). Dolayısıyla kurumlar, hedef kitlelerde nasıl hatırlanmak ve bilinmek istiyorlarsa kurumsal yapılarına uygun renkleri tercih ederek mesajlarını iletmelidirler. 


\subsection{Kurum Sloganı}

Kurum sloganı, kurumun rakiplerden farklılaşmasına, hedef kitlelerin algılarında yer etmesine, kurumun bilinirliğinin sağlanmasına, kurumun mesajını ve vaatlerini hedef kitlelere iletilmesine yardımcı olan önemli bir görsel kimlik bileșenidir. Kurumlar, hedef grupların kolay hatırlayacağı, basit, etkili, kısa, anlaşılır ve olumlu duygular çağrıștıracak sloganlar belirlemelidirler (Silsüpür, 2020, s. 129).

\subsection{Kurum Tipografisi ve Yazı Karakteri}

Kurumların yazı aracılığıyla iletişimlerinde ve tanıtım faaliyetlerinde tutarlı görünüm kazanmasında önemli olan tipografi de (Rizea \& Munteanu, 2013) tercih edilen yazı karakteri; kolayca ayırt edilmeli, rahat okunmalı ve bütün iletişim çalışmalarında aynı yazı karakteri tercih edilmelidir (Bayçu, 2012b, s. 80). Harfler, tipografinin en önemli unsurunu oluşturmakta, rakamlar ve noktalama işaretleri ise sonra gelmektedir. Tipografi tasarımında ilk önce yazı karakteri fontu belirlenmeli ve sürekli aynı biçim kullanılmalıdır (Tuna \& Tuna, 2007).

Tipografi ve yazı karakterinde, ince çizgili, dar ve uzun harflerin nezaket ve zarafeti; yuvarlak, geniş harflerin dostluğu; büyük harfler otoriteyi, gücü; küçük harfler cesareti ve mütevazılı̆̆ı, el yazısı güveni, neşeyi ifade etmekle birlikte, yuvarlak çizgiler kadınlara ve köșeli harfler ise erkeklere yönelik çağrışımlar oluşturmaktadır (İslamoğlu \& Fırat, 2016).

Kurumların hedef kitlelere doğru mesajı vermeleri için önce kurum felsefesi doğrultusunda kurumun neden var olduğunu ve nereye varmak istediği iyi şekilde anlaması gerekmektedir.

\subsection{Kurum Logosu/Amblemi}

Logolar, kurumları temsil eden, onların özelliklerini yansıtan anlam yüklü ve özel tasarlanmış semboller ya da biçimlerdir (Akıncı, 1998, s. 105). Logo, kurumların görsel olarak farklılaşmasına ve rakiplerinden ayırt edilmesine yarayan, hedef grupların kurumları kolayca hatırlamasını sağlayan șekil ve yazıyla oluşturulan görsel kimlik bileșenidir (Silsüpür, 2020, s. 125). Görsel kimliğin bir öğesi olan logo, hedef kitlelerin kurumları üçgen, kare, dikey, yatay ${ }^{1}$ gibi geometrik șekillerle tanınmasına yardımcı olan ya da kurum harflerinden meydana getirilen tasarım ürünleridir (Ries \& Ries, 2007; Rizea \& Munteanu, 2013). Logolar, kurumların bilinmesinde, hatırlanmasında ve dikkat çekmesinde önemli değere sahip görsel tasarım ürünleridir.

Görsel kimliğin temelini oluşturan logo ve amblem tasarımları kurum felsefesinin kısa sürede algılanmasını sağlayan görsel dildir (Bayraktaroğlu \& Çalış, 2010). Dolayısıyla logolar, kurum felsefesini yansıtan kurumun amaçları, var olma sebepleri, mesajları, tarihi gibi içerikleri, hedef kitlelere uzun uzun anlatılması yerine görsel öğeler yardımıyla ve etkileyici biçiminde anlatılmasıdır. Logolar, kurum isminin yazılış biçimini, kurumun yapısını ve karakterini açıklamaya yarayan harf ve baskı şeklindeki özel tasarlanan görsel sembollerdir. Amblem ise, hedef kitlelerin zorlanmadan hatırlayabileceği ve onlarda farkındalık oluşturabilecek, logoyla beraber kullanılan sembollerdir. Dolayısıyla logo için kurum isminin sanatsal olarak yazmak yeterliyken, amblem için görsel tasarımlarla bir bütün oluşturulması gerekmektedir (Ak, 1998, s. 105).

Logolar, bir özneyi, nesneyi ve kavramı açılkayan şekil temelli semboller; amblem ise yapısında kelime olmayan, şekil, resim, görüntü, rakam veya harflerden oluşan semboller 
olarak ifade edilmektedir (Tuna \& Tuna, 2007). Logolar; kurumları, ürün ve hizmetleri tanıtmaya yarayan, iki ya da daha fazla tipografik karakterin birleştirilmesi ve kelime gruplarıyla oluşturulurken; amblem ise, içeriğinde kelime barındırmayan, nesnel ve soyut görsellerle oluşturulan sembollerdir (Becer, 2002, s. 194-195). Örnek olarak, Görsel 1'deki Türk Hava Yolları (Turkish Airlines) yazısındaki kurum ismi logoyu açıklarken; kırmızı daire içerisindeki yaban kazını temsil eden beyaz görsel ise amblemi ifade etmektedir (Silsüpür, 2020, s. 127).

Genel olarak logo ve amblem arasındaki ayrıma dikkat edilmese ve aralarındaki farklılıklara bakılmasa da, iki kavram arasında ufak farklılık olduğu açıktır. Sonuç olarak hedef kitleler logo veya amblemi görsel ve görsel olmayan öğelerin birleşimi olarak bir bütünlük içerisinde değerlendirdiği tasarım ürünleri görmektedir.

\section{(2) \\ TURKISH AIRLINES

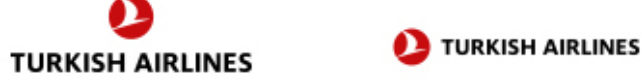

Görsel 1. Türk Hava Yolları logo ve amblem örnekleri (Turkishairlines, 2021).

Marka olmanın ve kurumsallaşmanın yolu iyi bir logoya sahip olmak ve hedef kitleyi etkilemekten geçmektedir (Topçu, 2017, s. 161). Bu sebeple logo tasarlanırken ve oluşturulurken şu konulara dikkat edilmesi gerekmektedir (Knapp, 2003, s. 100-101; Clow \& Baack, 2016):

- Kurum ismiyle uyumlu olmalıdır.

- Kolayca fark edilebilir ve tanınabilir olmalıdır.

- Etkileyici olmalı ve dikkat çekmelidir.

- Basit, kalıcı ve özgün olmalıdır.

- Herkesin okuyabileceği yazı karakteriyle tasarlanmalıdır.

- En fazla iki font tercih edilmelidir.

- En fazla üç renk tercih edilmelidir.

- Tasarımlar göze hitap etmeli (estetik olmalı) ve çağın gereklerine uygun şekilde hazırlanmalıdır.

Görsel kimliğin önemli bir bileșeni olan logo, diğer kimlik öğeleriyle uyum içinde tasarlanmalı ve hedef kitlelerde dikkat çekici bir bütünlük oluşturmalıdır.

\section{Araştırmanın Metodolojisi}

\subsection{Araştırmanın Amacı ve Önemi}

Kurumsal kimliği görünür ve bilinir kılan görsel kimlik, markayı hedef kitleye kabul ettirmede, gücünü göstermede, değerini koruma ve yükseltmede çok önemli işleve sahiptir. Araştırmanın amacı Türk Sineması'nda faaliyet gösteren yapım şirketlerinin görsel kimliğin önemli unsurlarından biri olan logolarını incelemektir. Bu bağlamda örneklem olarak seçilen BKM logosunun ne anlama geldiği, ne tür göstergeler içerdiği ve vermek istediği mesajları 01.05.2021-15.05.2021 tarihleri arasında içerik analizi yöntemiyle çözümlenmiştir. Çalışmada ayrıca şu sorulara cevap aranmıştır.

1. Yapım şirketi logosunun biçimsel özellikleri nelerdir?

2. Yapım şirketi logosunun tipografisi nasıldır?

3. Yapım şirketi logosunda hangi renkler kullanılmıştır? 
4. Yapım şirketi logosundaki renkler neden tercih edilmiştir?

5. Yapım şirketi logosunun özellikleri nelerdir?

6. Yapım şirketi logosunun alternatif tasarımları mevcut mudur?

7. Yapım şirketi logosu hakkında internet sitesinde bilgi var mıdır?

8. Yapım şirket logosunu bütün mecralarında orijinal tasarımına bağlı şekilde kullanmakta midır?

9. Yapım şirketi logosu markayı temsil edebilmekte midir?

10. Yapım şirketi logosu görsel kimliğe uygun mudur, görsel kimliği tamamlamakta midır?

Görsel kimlik çalışmaları, markaların kendilerini keşfetmeleri ve sağlam bir zeminde çalışmalarını yürütmeleri için önemli veriler sunmaktadır. Uzun ömürlü ve başarılı marka yaratmak güçlü bir görsel kimliğe, logoya sahip olmakla mümkündür. DergiPark ve YÖK Tez Merkezi'nde "logo", "sinema” ve "Türk Sineması" anahtar kavramlarıyla tarama yapılmış herhangi bir makale ve teze rastlanmamıştır. Alan yazında pek çok sektörde farklı markaların logoları üzerine çalışma olmasına karşın, sinema endüstrisi ile ilgili özellikle de yapım şirketleri bağlamında herhangi bir çalışmanın olmadığı saptanmıştır. Bu bağlamda araştırma çalışma konusu itibariyle alanın ilk araştırmalardan biridir ve sonraki çalışmalar için büyük önem taşımaktadır. Araştırma literatüre güncel katkı sağlamakla birlikte, Türk Sineması değerler zincirinin farklı aşamalarında faaliyet gösteren pek çok şirketin kurumsal kimlik çalışmaları içinde değerlendirilebilecek veriler sunmaktadır.

\subsection{Araştırmanın Evren ve Örneklemi}

Araştırmanın evrenini Türk Sineması'ndaki tüm yapım şirketleri oluşturmaktadır. Türkiye'de faaliyet gösteren Sinema Meslek Birliklerinden TESIYAP, FIYAB ve SE-YAP üyeleri baz alındığında 854 film yapım şirketi araştırma evrenine dahil olmaktadır. $\mathrm{Bu}$ evren içerisinde son yıllarda öne çıkan ve en çok film üreten şirket olan BKM örneklem olarak seçilmiştir. BKM, 2019 verilerine göre, bugüne kadar 71 filmin yapımcılığını üstlenmiştir. BKM hem film üretimi hem hasılat sayıları hem de kurumsal kimlik kullanımı bağlamında çalışmaya örneklem oluşturabilecek niteliklere sahiptir. BKM'nin Türk Sineması'nda bilinen, tanınan bir yapım şirketi olması ve dolayısıyla görsel kimliğinin ön planda olması da örneklem seçiminde belirleyici olmuştur.

\subsection{Araştırmanın Yöntemi}

Araştırmada görsel kimliğin en önemi unsuru olan logo incelenmiştir. BKM logosu logoyu oluşturan, temel öğeleri olan font, tipografi ve renk bağlamında derinlemesine analiz edilmiştir. BKM’nin markasının adının çözümlenmesi ile başlayan süreç eski ve yeni logoların karşılaştırmalı çözümlenmesiyle devam etmiştir.

Araştırmada içerik analizi yönteminden yararlanılmıştır. İçerik analizi, "iletişimin belirgin yazılı/açık içeriğinin objektif, sistematik ve niceliksel tanımlarını yapan bir araştırma tekniğidir" (Berelson, 1952, s. 7). İçerik analizi; "Metinlere ve kullandıkları bağlamlara yönelik anlaml, tekrarlanabilir ve geçerli çıkarımlar yapmak için faydalanılan bir araştırma tekniği" (Krippendorff, 1980, s. 18); olarak açıklanmakta içerik analizinde yapılan temel işlemin birbirine benzeyen verileri belirli kavramlar ve temalar çerçevesinde bir araya getirerek, okuyucunun anlayabileceği bir biçimde düzenledikten sonra yorumlamak olduğu ifade edilmektedir (Yıldırım \& Şimșek, 2006). İçerik analizi, bir grup metin kodlayıcı arasında benzer sonuçları elde edebilmek amacıyla, politik konuşmalardan, reklamlardan, gazete ve dergi makalelerinden oluşan çok çeşitli verilerin 
analizine imkân sağlayan ve sosyal bilimlerde çok sık kullanılan yöntemlerden biridir (Gürbüz \& Tarhan, 2019).

"Berelson, (aktaran Aytekin \& Oğuzcan, 2020) içerik analizi yöntemini, sosyal bilimler ve medya çalışmaları için çok yönlü kullanılabilecek bir araç olarak tarif ederken, yöntem, herhangi bir görsel ya da işitsel içerik üzerinde uygulanabileceği gibi yazılı bir metinde de bulunan kelimelerin açı kodlama kurallarına göre daraltılıp kategorize edilerek daha az içeriğe sıkıştırılması suretiyle elde edilen sistematik ve tekrarlanabilir bir teknik olarak ifade etmiştir".

İçerik analizinde önemli bir aşama olan kategorizasyon, basitçe sınıflandırmanın ötesinde düşünsel çaba gerektiren bir anlamlandırma aşamasıdır (Bilgin, 2014, s. 8). Araştırmada Özlem Topçu'nun (2017), "Kurumsal Kimlik Oluşturmada Bir Logonun Markaya Etkisi" başlıklı çalışması için tasarladığı kategorizasyondan yararlanılarak, kavramsal çerçeve doğrultusunda yeniden oluşturulan kategorizasyon (Logo Fontu, Logo Hattı, Renk, Sınırlandırma) kullanılmıştır.

\section{BKM Tarihçe ${ }^{2}$}

BKM, Türk kültür sanat tarihinde 27 yllık geçmişe sahip önemli yapım şirketlerinden biridir. BKM, Necati Akpınar ile Yılmaz Erdoğan'ın 11 Kasım 1994 tarihinde Beşiktaş'ta bulunan "Mıstık Sineması"nı tiyatro salonuna dönüştürmesiyle kurulmuştur. Necati Akpınar, 1980 yılından itibaren Levent Kırca ve Yasemin Yalçın Tiyatrosu'nda yönetici olarak görev yapmıştır. Yılmaz Erdoğan ise 1987 yılında Nöbetçi Tiyatro'da amatör oyuncu ve yazar olarak tiyatroya adım atmış bir sanatçıdır. Yeterli sermayeleri olmamasına rağmen çok kötü durumdaki tiyatroyu restore edip faaliyetlerine başlamışlardır.

Tiyatro ile başlayan üretim alanı televizyon, sinema ve konser etkinlikleri ile çeşitlenerek artmıştır. Bugün BKM çatısı altında BKM Tiyatro, BKM Film ve BKM Organizasyon olarak üç ana sektörde faaliyetler sürdürülmektedir.

BKM Tiyatro, yıllar içerisinde yüz binlerce izleyiciye ulaşan ve günümüze her biri birer klasik halini almış olan oyunlar ve gösteriler sahneye koymuştur. Güldür Güldür Show, Çok Güzel Hareketler Bunlar, Güldüy Güldüy Show gibi tiyatro ve televizyonu birleştiren başarılı içerikler üretmiştir. BKM Mutfak ise, tiyatronun çırak kültürünü devam ettiren bir eğitim içerisinde bir TV efsanesi olarak kabul edilen "Bir Demet Tiyatro" ile başlayan televizyon macerasını daha kurumsal bir hale getirmiştir.

BKM Organizasyon adı altında da yurt içinden ve yurtdışından tanınmış isimleri, sanatçları, dinleyicileri ile buluşturan konserler, etkinlikler düzenlenmiştir.

BKM Film ise 2000 yılında kurulmuş ilk projesi "Vizontele" (2001) ile gișe rekoru kırarak büyük başarı elde etmiştir. "Kelebeğin Rüyası" (2013) ile Akademi Ödülleri'nde Türkiye'nin aday adayı filmi olmuştur.

Tiyatroya, televizyona, sinemaya, dijital platformlara, oyunlar, diziler, programlar, sinema filmleri üreten BKM, Beşiktaş'ta başladığı yolculuğunun sınırlarını her geçen gün genişleterek kültüre dair projelerine devam etmektedir.

\section{Türk Sineması'nın Öncü Yapım Şirketi BKM}

Çalışkan'ın (2019) derlediği verilere göre, BKM 2000 yılında başladığı film yapım sürecinde bugüne kadar 67 film üretmiștir. ${ }^{3}$ Filmlerin toplam izleyici sayısı 98.782 .252 kişi, toplam hasılat 1.005.351.506 TL'dir. ${ }^{4}$ Televizyona (TV) ise, dizi ve program olarak 
37 yapım gerçekleştirilmiştir. Sinema ve TV için üretilen içeriklerin toplam sayısı 106 'dır (Tablo 1). BKM, son yılların en çok film üreten, en fazla seyirci sayısına ve gişe hasılatına ulaşan yapım şirketidir (Box Office Türkiye, 2020).

Tablo 1. 2019 Yılı İtibarıyla BKM Yapımları (Çalışkan, 2019).

\begin{tabular}{|c|c|c|}
\hline \multicolumn{3}{|c|}{ BKM Yapımları } \\
\hline Film & Dizi & TV Programı \\
\hline 67 & 24 & 13 \\
\hline
\end{tabular}

BKM, başarılı prodüksiyonları ile sektörün öncü yapım şirketlerinden bir haline gelmiştir. Netflix ile yaptığı anlaşma ile ilk defa bir Türk filmi, Organize İşler Sazan Sarmalı (2019), aynı anda hem vizyonda hem de dijital platformda gösterime girmiştir. BKM, hem Netflix'e hem de Blu TV'ye dizi film çekmiştir. Zengin ve farklı içerik türlerine sahip olan BKM, TAFF Pictures ile pandemi öncesinde yeni bir dijital platform projesi üzerinde çalışmaktaydı.

\section{Bulgular}

\subsection{Beşiktaş Kültür Merkezi İsmi}

Şirketin ismi Beşiktaş Kültür Merkezi, şirketin faaliyet gösterdiği ve yaptığı işi tanımlayan, açıkça ortaya koyan bir isimdir. BKM; tiyatro, sinema, konser ve dizi gibi sanatın kültürle buluştuğu pek çok faaliyet gerçekleştirmektedir. Bu anlamda kültüre büyük katkısı vardır ve şirketin isminde vurgulandığı gibi "kültür" işlevi görmektedir.

Şirketin isminde yer alan Beşiktaş, İstanbul'un en önemli ve en bilinen ilçelerinden biridir. Gerek tarihi geçmişi, turistik özellikleri gerek ise Türk futbolunun önemli takımlarından Beşiktaş'a ev sahipliği yapması, adını vermesiyle Beşiktaş ilçesi sadece İstanbul için değil, Türkiye için de çok popüler ve bilinen bir ilçe konumundadır. Sosyo-ekonomik yapı olarak ise genel anlamda orta-üst sınıfın yaşadığı bir ilçedir.

Beşiktaş, üniversite öğrencilerinin, gençlerin yoğun ilgi gösterdiği, oldukça hareketli bir ilçedir. Çünkü kültürel ve sanatsal faaliyetler anlamında zengin ve popülerdir. BKM, bu birikim üzerine faaliyet gösteren ve bu birikimlere çok önemli katkılar yapan bir kurum olmuştur. İlçenin marka değerini adında taşıyarak hem nerede faaliyet gösterdiğini belli etmiş hem de kendi markasına değer katmıştır.

Beşiktaş Kültür Merkezi'nin çok kolay, anlaşılır, akılda kalıcı bir ismi vardır. Logoya da bu özellikler yansıtılmıştır. Logonun söylenişi de çok kolaydır. İnsanların genel olarak bildiği, popüler olan bir ilçenin adının kullanılması akılda kalıcılığı kolaylaștırmıştır. Zintzmeyer'e (aktaran Bayçu \& Ustaoğlu, 2015) göre logo, kurumun ya da markanın bir dişavurum şeklidir. Beşiktaş Kültür Merkezi de bu anlamda kendi marka ismine köprü olacak bir logoyu seçmiştir.

\subsection{BKM Logoları}

BKM, 27 yıllık tarihinde iki farklı logo kullanmıştır. Kuruluş yılından 2014 yılına kadar Görsel 2'deki BKM logosu kullanılmıştır. El yazısını çağrıștıran ve bir elips şeklinin içinde birbirinin içine geçmiş olan BKM harfleri, iki dağ ya da kitap sayfası ortasına benzer bir şekil arasına yerleştirilmiştir. Bu logonun sık kullanılan turuncu versiyonu göz önüne alındığında BKM’nin iki dağ arasında doğan güneş imgesini çağrıştırdığı söylemek mümkündür. Nasıl güneş tüm canlılara can veriyorsa BKM'de kültür-sanat dünyasına can vermekte, beslemektedir. Suyun aktığı verimli vadi üzerinde yükselen BKM, doğayı, doğallığı, üretkenliği/bereketi ve özgürlüğü çağrıștırmaktadır. Akla gelen bir diğer imge olan kitapta BKM'nin faaliyet alanı olan kültür ile örtüşen bir yapı göstermektedir. 
$\mathrm{Bu}$ logonun siyah ve beyaz renkte olan versiyonları da kurumsal kimlik çalışmalarında kullanılmıştır. Bu logo son olarak 2014 yılında vizyona giren yönetmenliğini Ozan Açıktan'ın yaptığı Silsile filminde yer almıștır.
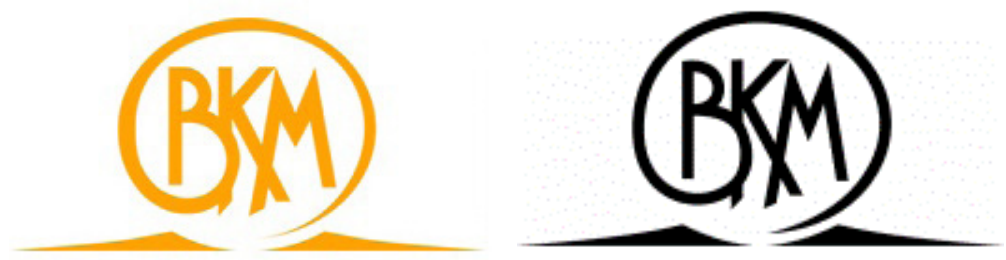

Görsel 2. BKM Eski Logoları

BKM, 2014 yılında yaptığı kurumsal kimlik yenileme çalışmaları ile daha sade, belirgin ve dikkat çeken bir logoyu kullanmaya başlamıştır. Logonun yapım şirketinin baş harflerden oluşan yapısı bozulmadan yeni bir düzenlemesi yapılmıştır. Kurum kimliğinin bilinçsizce ve gereğinden fazla yenilenmesi veya tamamen değiştirilmesinin kurumları olumsuz etkilediğini belirten Bayraktaroğlu ve Çalış (2010), çözüm yolu olarak kurumların amblem ve logo tasarımlarını tamamen değiștirmek yerine yalınlaștırma yoluna gitmeleri gerektiğini önermektedir. Bu sayede kurumların görsel tanınırlık imajı devam etmiș olacaktır.

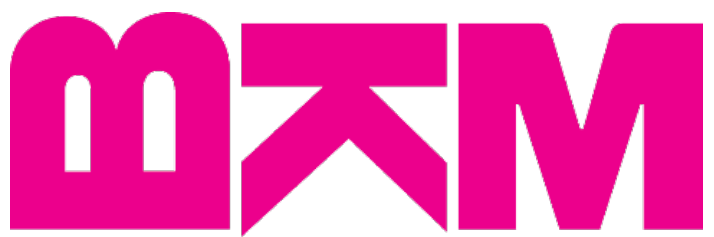

Görsel 3. BKM Yeni Logo

BKM'nin yeni logosu, BKM harflerinin farklı yönlere bakan dizilimlerinin yan yana gelmesi ile oluşan bir tasarıma sahiptir (Görsel 3). Bu logonun, diși, erkek ve siyahbeyaz versiyonları da bulunmaktadır (Görsel 5). Dişi logomagenta bir dikdörtgen içinde beyaz renkte, erkek logo magenta renginde, siyah olan versiyonda yazı siyah renkte kullanıma sunulmuştur.

\subsection{Tipografi Kullanımı}

Beşiktaş Kültür Merkezi'nin (BKM) logosu, baş harflerinden oluşan kısaltma șeklindedir (Görsel 3). Bu sayede marka ismi ile logo bütünleșmiştir. Logo, markanın adının kolayca akla gelmesine, akılda kalmasına, adına çağrıșım yapmasına müsait bir yapıdadır. Kısa ve özlü olan kısaltmaların hem görsel hem de fonetik olarak algılanması kolaydır. Ayrıca kısaltma logoları birden fazla tasarım seçeneği sunabilmektedir. BKM logosu bu özellikleri taşımaktadır.

BKM logosu, Türkçe imla kurallarına göre klasik şekilde yan yana dizilmiş baş harflerin büyük yazılışı biçiminde oluşturulmamıştır. Logoya hareket, farkındalık, gizem ve özgünlük kazandıracak şekilde harfler farklı şekillerde dizilmiştir. B harfi ön tarafı üstte gelecek, $\mathrm{K}$ harfi ön tarafı alta gelecek, M harfi de düz şekilde yan yana getirilerek BKM logosu oluşturulmuştur. Logo, ilk bakışta algıda organizasyon özelliği sayesinde rahatlıkla algılanırken bir farklılık içerdiği de dikkat çekmektedir. Ayrıca harflerin diziliminden BKM'nin farklı alanlarda (tiyatro, televizyon, sinema vb.) farklı türlerde içerikler ürettiğine bir gönderme de yapıldığı varsayılabilir. 
Logodaki baş harfler, Türkçedeki kısaltma yazım kurallarına uygun olarak büyük olacak şekilde kullanılmıştır. BKM logosunun tipografisi, çok keskin olmayan ve kalın/dolgun hatlara sahiptir. Kalın/dolgun harfler logoyu daha görünür kılmakla birlikte, markanın gücüne de vurgu yapmaktadır. Keskin olmayan hatlar daha yumuşak, sıcak, kendine çeken bir logo atmosferi oluşturmuştur. Logonun tipografisinin SansSerifli olması yani Arial veya Verdana gibi, başı ve sonu düz biten harflerden oluşması, karmaşayı önlemiş, sadeliği getirmiş, algılanmayı kolaylaştırmıştır.

Gözü yormayan, markayı görünür kılan, akılda kalıcı, yalın, hatırlanması kolay bir tipografi kullanılmıştır. Bu anlamda BKM logosu hedef kitlenin zihninde hemen yer edebilecek ve marka ile bağlantıya geçebilecek bir yapıdadır. Ayrıca kalın/dolgun bir fontun kullanılması rengin de belirgin bir şekilde ortaya çıkararak kendini göstermesini sağlamıștır.

BKM'nin kurumsal internet sitesinde yer alan basın odası sayfası linkindeki kurumsal dokümanlar içinde logonun dişi, erkek ve siyah-beyaz olmak üzere, AL, PSD ve JPEG formatlarında indirilebilir şekilde üç ayrı tasarımı mevcuttur. Bu tasarımlar, uygun içeriklerin görsellerine göre zeminde BKM logosu belirgin olacak şekilde kullanılmak için geliştirilmiştir. BKM'nin son logosu 2014'ten sonra çekilen 42 filmde 4 farklı renkte kullanılmıştır (Görsel 4). Zemine göre bu esnek değişim logo için alternatif kullanım kolaylığı sağlayarak markanın kurumsal kimliğinden ödün vermeden görünür kılınmasına yardımcı olmaktadır. Aynı zamanda baskı çalışmalarında grafikerlere de kolaylık sağladığı gibi logoların gerek renk gerek boyut bağlamında sınırlandırmasını da ortadan kaldırmakta yaratıcı işlerin çıkmasına zemin hazırlamaktadır.
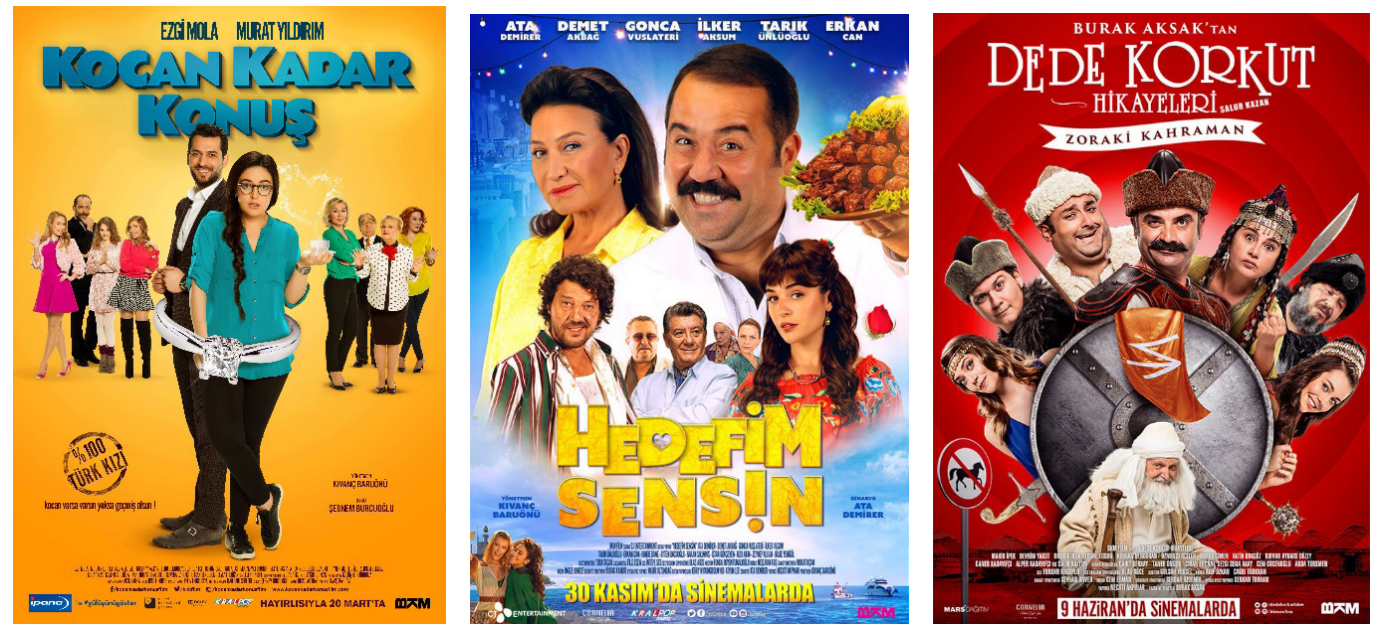

Görsel 4. BKM Logosunun Film Afişlerinde Kullanımı

Bununla birlikte kurumsal dosya içerisinde BKM'nin 25. yıl için tasarladığı logonun yine üç ayrı türde (dişi, erkek ve siyah beyaz) ve yine farklı formatlardaki tasarımları yer almaktadır (Görsel 5). 


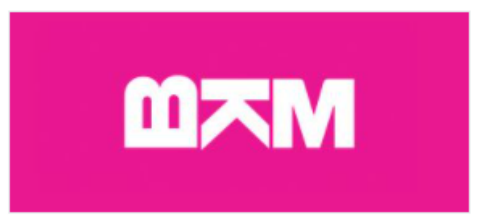

BKM Logo Diși (AI, PSD, JPG) $\downarrow . z \operatorname{lp}(1,6 \mathrm{MB})$

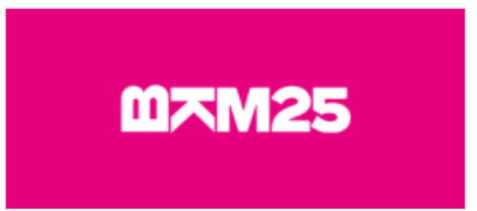

BKM 25.Yıl Logo Diși (Al, PSD, JPG) $\downarrow . z \operatorname{lp}(1,5 \mathrm{MB})$

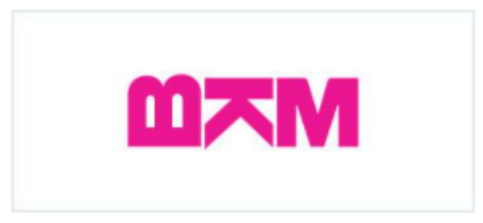

BKM Logo Erkek (AI, PSD, JPG) $\downarrow . z 1 p(1,6 \mathrm{MB})$

\section{mスM25}

BKM 25.Yıl Logo Erkek (AI, PSD, JPG) $\downarrow . z \operatorname{lp}(1,5 \mathrm{MB})$

\section{mXM}

BKM Logo Siyah Beyaz (AI, PSD, JPG) $\downarrow . z 1 p(1,6 \mathrm{MB})$

\section{mスM25}

BKM 25.YII Logo Siyah Beyaz (AI, PSD, JPG)

$\downarrow . z \operatorname{~zlp~}(1,5 \mathrm{MB})$

Görsel 5. BKM Logosunun Farklı Versiyonları

BKM logosunun sade ve kalın tipografisi ve farklı versiyonlarının olması her türlü zemine uygulanabilme kolaylığını da beraberinde getirmiştir. Logolar firmaya ait büyüklü küçüklü bütün basılı materyaller üzerinde ve her türlü reklamda kullanıldığından kolay basılabilir nitelikte olmalıdır. Özellikle baskılı işlerde çok sınırlandırıcı bu durum BKM logosunda aşılmış görülmektedir. Grafikerin yaratıcı bakış açısını sınırlandırmayan bu durum başarılı görsel işlerin de önünü açmaktadır. Bu sayede BKM logosu pek çok görsel malzemede rahatlıkla kullanılabilmiştir.

\subsection{Renk Kullanımı}

Logonun ana rengi magentadır. Sıcak bir renk olan magenta, kırmızı ve mavinin bir karıșımı olan ara bir renktir. BKM Logosunun renk değerleri ise CMYK olarak C0, M100, Y0, K0; RGB olarak ise R256, G0, B140'tır.

Magenta genel olarak markaların çok tercih etmediği farklı bir renktir. Bu farkındalık ile birlikte BKM logosunda tek rengin kullanılması algılanmayı ve okunmayı kolaylaştırmıştır. Logodaki kalın font tercihi rengin daha çok ön plana çıkmasını da sağlamıştır. Bu yüzden BKM logosu hemen ilk bakışta fark edilebilmektedir.

Renkler, hedef kitlenin zihinlerinde kurum ya da marka imajını destekleyen anlamlar yaratmaktadır (Madden, Hewett, \& Roth, 2000'den aktaran Bayçu \& Ustaoğlu, 2015). Magenta, mavi ve kırmızının dikkat çekiciliğinde parçalar taşıdığı gibi olumlu duygular uyandıran, özgürlügüu, mutluluğu, romantikliği, baharı, umudu, sakinliği, ilhamı, merhameti, doğayı, çiçekleri çağrıştıran bir renktir.

Magenta, aynı zamanda mora yakın bir renktir. Mor renk ise gizem, lüks, asalet, zenginlik, soyluluk ve özgürlük algılarını oluşturmaktadır (Çağan, 2005, s. 52). Aynı zamanda imparatorluk rengi olarak da bilinmektedir. Bununla birlikte Beşiktaş'ta sıkça bulunan İstanbul'un simgelerinden Erguvan'da ${ }^{5}$ magenta rengindedir. BKM, Beşiktaş'ta yer alan bir kültür merkezi olarak nasıl adında da Beşiktaş’a yer verdiyse logosunda da buna vurgu yapmak düşünmüş olabilir. Bu şekilde düşünüldüğünde BKM, Beşiktaş ile sadece adı ile değil simge ağacı, rengiyle de bütünleşmiş olarak kurumsal kimliğine hem tarihi bir ruh hem de anlamlı bir görsellik eklemiş olmaktadır.

Magentanın dışında logonun beyaz ve siyah versiyonları da bulunmaktadır. İnsan gözünün en iyi algıladığı durum siyah fon üzerine beyaz, beyaz font üzerine siyah renktir. 
BKM logosunun çeşitli projelerde kullanılmış bu tür versiyonları bulunmaktadır. Özellikle koyu fonlarda beyaz, açık fonlarda siyah renk kullanılarak logonun kolayca algılanması sağlanmış, markanın imzası logo ile atılmıştır. BKM’nin web sitesinde film bölümünde yer alan afişler tarandığında yeni logo kullanılan afişlerin 28'inde logonun beyaz, 11'inde magenta, 2'sinde siyah ve sadece 1'inde (Ekşi Elmalar-2016) filmin isminin renginde özel bir kullanım olduğu görülmektedir (Tablo 2).

Tablo 2. BKM Logosunun Film Afişlerindeki Renk Kullanımı

\begin{tabular}{|c|c|c|c|c|}
\hline \multicolumn{5}{|c|}{ Logonun Film Afişlerindeki Renkleri } \\
\hline Beyaz & Magenta & Siyah & Özel & Toplam \\
\hline 28 & 11 & 2 & 1 & 42 \\
\hline
\end{tabular}

BKM'nin web sayfasında kurumsal dokümanlar kısmındaki logonun diși versiyonunda magenta dikdörtgen içinde beyaz renkte zeminli bir logo tasarımı da bulunmaktadır (Görsel 5). Zeminli kullanımlardaki bu magentalı kullanım logonun patlamasına yani hemen fark edilmesine yol açmaktadır. BKM logosunun içerik analizi yapıldığında logonun farklı versiyonları olsa da logo fontu olarak SansSerifli, logo hattı olarak yumuşak, sınırlandırma anlamında sadece dişi logo da dikdörtgen bir sınırlandırmanın olduğu, renk olarak magenta ağırlıkta olmak üzere siyah ve beyaz rengin de kullanıldığı saptanmıştır (Tablo 3).

Tablo 3. BKM Logosu İçerik Analizi Tablosu

\begin{tabular}{|l|c|c|c|}
\hline \multicolumn{3}{|c|}{ BKM Logo } \\
\hline Logo Özellikleri & BKM Logo Dişi & BKM Logo Erkek & $\begin{array}{c}\text { BKM Logo } \\
\text { Siyah-Beyaz }\end{array}$ \\
\hline Logo Fontu & SansSerifli & SansSerifli & SansSerifli \\
\hline Logo Hattı & Yumuşak & Yumuşak & Yumuşak \\
\hline Renk & Beyaz & Magenta & Siyah \\
\hline Sınırlandırma & Dikdörtgen & - & - \\
\hline
\end{tabular}

\section{Sonuç ve Değerlendirme}

Bugünün rekabet koşullarında dikkat çekmek ve hedef kitlede yer edinmek, kurumları görsel açıdan açıklamakla mümkündür. Kurumlar; isim, renk, slogan, yazı karakteri, logo gibi sadece kendilerine özgü tasarımlarla bilinirliklerini sağlamakta, bu somut görselliklerle de hedef kitlelerin hafızalarında yer edinmekte ve imajlarını güçlendirmektedirler.

Logolar, kurumların/markaların ne yaptığını ve kendilerini nasıl tanımladığını da hedef kitlelere anlatan sembollerdir. Kurumlar sahip oldukları kurumsal birikim, misyon ve vizyonları doğrultusunda logolarını tasarlayıp, hedef grupları etkilemeli ve kurumsal imajlarına olumlu yönde katkı sağlamalıdırlar. Kurumların tanınmasında önemli bir kimlik unsuru olan logo, görsel olarak hedef kitleleri etkilemekte ve dikkat çekmektedir. Logolar şekil esaslı görsel kimlik öğesi olduğu için, kurumlar vermek istedikleri mesajları bu anlam yüklü unsurdan yararlanarak hedef kitlelere iletmektedirler. Bu sebeple, logolar tasarlanırken kurum felsefesi, kurumun var olma sebebi ve mesajı iyi analiz edilmelidir. Ayrıca logo tasarımında diğer görsel kimlik bileşenleri olan yazı karakteri ve renk iyi belirlenmeli, kurumun logosu bu öğelerin bütünleșmesiyle oluşturulmalı ve hedef kitlede etki sağlanmalıdır. Bu bağlamda çalışmada, BKM’nin kurumsal logo çalışmaları görsel kimlik açısından değerlendirilmeye alınmış ve sonuçlar sunulmuştur.

Türkiye'nin son yıllarda en çok film üreten, seyirci ve hasılat sayılarında önde olan şirketi BKM, kurumsal yapısı ile de dikkat çekmektedir. BKM, tiyatro, televizyon, konser ve 
sinema gibi farklı kültür-sanat alanlarında faaliyet göstermektedir. Ulusal ve uluslararası pek çok projeye imza atan BKM'nin kurumsal kimliğin önemli unsurlarından biri olan görsel kimlik çalışmasını logo alt başlığı altında incelenen bu çalışmada, BKM'nin profesyonel bir yaklaşımla logosunu oluşturduğu ve kullandığı görülmüştür.

Kuruluşundan bugüne iki logo kullanan BKM son logosu, kurumun adının baş harflerinden oluşmaktadır. Logo, harflerinin dizilimi, büyüklüğü, seçilen fontu ile diğer yapım şirketi logolarından farklı şekilde kendini konumlandırmıştır. Tipografi ile bir bütün oluşturacak şekildeki renk seçimi de logoyu daha belirgin kılmıştır. Ana renk olarak seçilen magenta, taşıdığı olumlu duygular ve çağrışımlar nedeniyle logoyu güçlendirmiş, markaya artı bir değer kazandırmıştır. BKM logosu görsel kimliği tamamlayıcı, markayı ön plana çıkartan, onu her yerde temsil edebilecek bir tasarıma sahiptir.

Akılda kalıcılığı, okunması ve algılanması kolay yapısı yanında zemine göre ve farklı projelere uygun olacak şekilde alternatif hazır tasarımları olan BKM logosu, karşılaşılabilecek grafiksel sorunlarından önceden önüne geçmiştir. Hazır tasarımlar web sitesinden herkesin ulaşabileceği şekilde kullanıma sunulmuştur.

BKM logosu, gerek tipografi gerek renk kullanımı ve gerek uygulama alanları bağlamında incelendiğinde üzerinde düşünülmüş profesyonel bir çalışma yürütülmüş bir logo izlenimi vermektedir. Dengeli ve bütünlüklü bir tasarımı vardır. Logo, yapım şirketinin sosyal medya hesaplarında, baskılı içeriklerinde, ölçülerine, renklerine, özelliklerine dikkat edilerek başarıyla uygulanmıştır. $\mathrm{Bu}$ uygulamaları kurumun hem sosyal medya hesaplarında, hem film afișlerinde, hem basın kitlerinde hem web sitelerinde görmek mümkündür.

Kurumsal kimliği tamamlayan, görsel kimliği ön plana çıkartan ve markaya bilinilirlik, fark edilme, akılda kalıcılık anlamında değer katan BKM logosu, Türk yapım şirketlerinin görsel kimlik çalışmalarında örnek alması gereken bir kurumsal kimlik materyali olarak dikkat çekmektedir. Logo, Türk Sineması'nda kurumsallaşma ve görsel temsiliyet bağlamında sorunlar yaşayan yapım şirketleri için önemli çözüm önerileri sunmaktadır.

\section{Notlar}

1 Yön gösterici özelliğe sahip olan üçgen, denge hissini; daire, sonsuzluğu; kare, yaşam alanlarını ifade etmektedir (Ketenci \& Bilgili, 2006).

2 BKM tarihçe bilgisi kurumun web sayfasından alınarak yeniden düzenlenmiştir.

3 Çalışkan'ın (2019) verileri derlediği tarihten sonra BKM'nin 4 filmi daha vizyona girmiş ve BKM'nin yapımına imza attığı film sayısı 71'e yükselmiştir.

4 Gişe ve hasılat sayıları vizyona giren 69 BKM yapımı filmin sayılarıdır. Çalışkan'ın, 2019 için derlediği bu verilere, sonraki yıllarda vizyona giren BKM filmlerinin boxoficeturkiye.com'daki verileri eklenmiş̧ir. Ezel Akay'ın yönetmenliğini yaptığı 9 Kere Leyla filmi Netflix’te gösterime girdiği için tam olarak hasılat ve seyirci sayısı (izlenme sayısı) bilinemediğinden bu filmin gişe ve hasılat sayıları, toplam verilere eklenmemiştir.

5 Erguvan (Cercissiliquastrum), nisan ve mayıs aylarında açmaktadır. İstanbul'un hem Anadolu hem Avrupa yakasında Boğaz boyunca uzanmaktadır. İstanbul'da erguvan şenlikleri düzenlediği gibi İstanbul'un pek çok bölgesine erguvan ağaçları dikilmiş, İBB otobüslerinin bir kısmı erguvan rengine boyanmışıır.

\section{Kaynakça}

Abisel, N. (1994). Türk sineması üzerine yazılar. Ankara: İmge Kitabevi.

Ak, M. (1998). Firmalarda/markalarda kurumsal kimlik ve imaj. İstanbul: Işıl Ofset Sanayi Limited Şirketi. 
Akıncı, Z. B. (1998). Kurum kültürü ve örgütsel iletişim. İstanbul: İletişim Yayınları.

Aktepe, C., Baş, M., \& Tolon, M. (2009). Müşteri ilişkileri yönetimi. Ankara: Detay Yayıncllık.

Aytekin, M. (2017). The era of social media on the relationship between cinema and the audience: the example of "Sinemia". International Symposium of New Media from the Past to the Future, (s. 71-83). İstanbul.

Aytekin, M. (2020). Covid-19 sonrası Türk sinema endüstrisi üzerine bir inceleme. Turkish Studies , 15 (4), 69-93.

Aytekin, M., \& Oğuzcan, D. (2020). Kültürün yeniden üretimi bağlamında Türk kültüründeki oyun ve oyuncakların canlandırma filmlerde incelenmesi: rafadan tayfa dehliz macerası örneği. Tarih Okulu Dergisi (48), 3418-3449.

Bakan, Ö. (2011). Kurumsal kimlik ve imaj. A. Kalender, \& M. Fidan (Dü) içinde, Halkla ilişkiler (s. 289-310). Konya: Tablet Yayınevi.

Balmer, J. M., \& Gray, E. R. (2000). Corporate identity and corporate communications: creating a competitive advantage. Industrialand Commercial Training, 32 (7), 256262.

Bayçu, S. (2012a). Kurum kimliği, kültürü ve imajı. F. Uztuğ (Dü.) içinde, Kurumsal iletişim (s. 46-69). Eskişehir: Anadolu Üniversitesi Açıöğretim Fakültesi Yayınları.

Bayçu, S. (2012b). Kurumsal tasarım ve görsel kimlik. F. Uztuğ (Dü.) içinde, Kurumsal iletişim (s. 70-92). Eskişehir: Anadolu Üniversitesi Açıöğretim Fakültesi Yayınları.

Bayçu, S. U., \& Ustaoğlu, F. D. (2015). Kurum kimliği: logo ve rengin çağrışımları. Selçuk Üniversitesi Sosyal Bilimler Enstitüsü Dergisi (34), 27-40.

Bayraktaroğlu, A. M., \& Çalıș, E. (2010). Amblem ve logo tasarımlarında yalınlaștırmalar. Süleyman Demirel Üniversitesi Güzel Sanatlar Fakültesi Hakemli Dergisi Art-e, 3 (6), 1-22.

Becer, E. (2002). İletişim ve grafik tasarım. Ankara: Dost Kitabevi.

Berelson, B. (1952). Content analysis in communication research. Glencoe: The Free Press.

Bilgin, N. (2014). Sosyal bilimlerde içerik analizi: teknikler ve örnek çalışmalar. Ankara: Siyasal Kitabevi.

Bottomley, P. A., \& Doyle, J. R. (2006). The interactive effects of colors and products on perceptions of brand logo appropriateness. Marketing Theory , 6 (1), 63-83.

Bouchet, D. (2000). What is corporate image and corporate identity-and why do people talk so much about it?,. Mart 21, 2021 tarihinde http://www.busieco. ou.dk: http://www.busieco.ou.dk/ dom/priv/research/corporateidentity.pdf adresinden alındı

Box Office Türkiye. (2020, Şubat 15). Şubat 15, 2020 tarihinde BKM filmleri toplamda 100 milyon seyirciye doğru! https://boxofficeturkiye.com/haber/bkm-filmleritoplamda-100-milyon-seyirciye-dogru--2442 adresinden alındı

Cima, M. (2021, Mayıs 1). Film yapımcılarının rolü. Mayıs 1, 2021 tarihinde storyboardthat: https://www.storyboardthat.com/tr/articles/f/ yap\%C4\%B1mc\%C4\%B1n\%C4\%B1n-nesi adresinden alındı 
Clow, K. E., \& Baack, D. E. (2016). Integrated advertising, promotion, and marketing communications. United Kingdom: Pearson.

Çağan, M. (2005). Sizin renkleriniz. İstanbul: Bir Harf Yayınları.

Çalışkan, M. (2019, Kasım 17). Haber Türk. Kasım 17, 2019 tarihinde Yılmaz Erdoğan ve Necati Akpınar için her şey bu salonda başladı. https://www.haberturk.com/ yilmaz-erdogan-ve-necati-akpinar-icin-her-sey-bu-salonda-basladi-2540911 adresinden alındı

Çam, A. (2018). 1960-1975 yılları arasında Adana'da filmcilik ve sinemacılık işi. Galatasaray Üniversitesi İleti-ş-im Dergisi (28), 9-41.

Erkılıç, H. (2009). Düş şatolarından çoklu salonlara değişen seyir kültürü ve sinema. Kebikeç (27), 143-162.

Gökmen, S. (1973). Bugünkü Türk sineması. İstanbul: Fetih Yayınevi.

Grimes, A., \& Doole, I. (1998). Exploring the relationships between colour and international branding: a cross cultural comparison of the UK and Taiwan. Journal of Marketing Management, 14 (7), 799-817.

Gürbüz, S., \& Tarhan, A. (2019). Türkiye'nin ilk 500 sanayi kuruluşunun sponsorluk uygulamaları: kurumsal web sayfaları üzerine bir analiz. Akdeniz Üniversitesi İletişim Fakültesi Dergisi (31), 537-559.

Internatioal Federation of Film Producers Associations. (2010). Mayıs 1, 2021 tarihinde basic principles for film producers worldwide: http://www.fiapf.org/advocacy_ basic_principles.asp adresinden alındı

İslamoğlu, A. H., \& Fırat, D. (2016). Stratejik marka yönetimi. İstanbul: Beta Basım Yayım Dağıtım A.Ş.

Ketenci, H. F., \& Bilgili, C. (2006). Yongaların onbin yıllık gizemli dansı: görsel iletişim \& grafik tasarımı. İstanbul: Beta Basım Yayım Dağıtım A.Ş.

Knapp, D. E. (2003). Marka akll: Starbucks, Whirpool ve Hallmark'ın nasıl birer gerçek marka oldukları ve markalama başarılarının arkasındaki diğer sırlar. (A. T. Akartuna, Çev.) İstanbul: MediaCat Kitapları.

Köktürk, M. S., Yalçın, A. M., \& Çobanoğlu, E. (2008). Kurum imajı: oluşumu ve ölçümü. İstanbul: Beta Basım Yayım Dağıtım A.Ş.

Krippendorff, K. (1980). Content analysis: an introduction to its methodology. New York: Sage Publication.

Meyfilm. (2017, Ocak 5). Eylül 5, 2018 tarihinde prodüksiyon nedir? https://meyfilm. com/produksiyon-nedir/ adresinden alındı

Olins, W. (2002). Corporate identity. The Ultimate Resource Business, 1-6.

Özüpek, M. N. (2005). Kurum imajı ve sosyal sorumluluk. Konya: Tabet Kitabevi.

Peltekoğlu, F. B. (2004). Halkla ilişskiler nedir. İstanbul: Beta Basım Yayım Dağıtım A.Ş.

Ries, A., \& Ries, L. (2007). Marka yaratmanın 22 kuralı. (A. Özdemir, Çev.) İstanbul: MediaCat Kitapları. 
Rizea, R. D., \& Munteanu, A. R. (2013). Defining a coherent organisa-tional visual Identity-a qualitative analysis, network intelligence studies. Network Intelligence Studies, 1 (1), 102-117.

Silsüpür, Ö. (2014). Üniversite öğrencilerinin gözünde İstanbul Üniversitesi'nin imajı. Yüksek Lisans Tezi. Konya: Selçuk Üniversitesi Sosyal Bilimler Enstitüsü.

Silsüpür, Ö. (2015). Üniversite öğrencilerinin gözünde İstanbul Üniversitesi'nin imajı. Gümüşhane Üniversitesi İletişim Fakültesi Elektronik Dergisi , 3 (1), 263-288.

Silsüpür, Ö. (2020). Kurumsal sosyal sorumluluk ve marka imajı. Konya: Palet Yayınları.

Sinema Eseri Yapımcıları Meslek Birliği. (2021, Ocak 5). Ocak 5, 2021 tarihinde film yapım sürecinde yapımcının rolü nedir? http://www.se-yap.org.tr/yardim/ adresinden alındı

Şatana, N., \& Yücesoy, S. (2018). Türk sinemasında gelișen yapımcılık modelleri bağlamında günümüz yapımcılığının derinlemesine analizi. Dördüncü Kuvvet Uluslararası Hakemli Dergi, 1 (2), 95-115.

Şentürk, R., Gülçur, A. S., \& Eken, İ. (2017). Türkiye'de film endüstrisi (2011-2015). İstanbul: İstanbul Ticaret Odası Yayınları.

Topçu, Ö. (2017). Kurumsal kimlik oluşturmada bir logonun markaya etkisi. Yeni Medya Elektronik Dergi - eJNM, 1 (2), 157-163.

Tuna, M., \& Tuna, A. A. (2007). Kurumsal kimlik yönetimi. Ankara: Detay Yayıncllık.

Turkishairlines. (2021, Mayıs 10). Mayıs 10, 2021 tarihinde https://www.turkishairlines. com/tr-eg/basin-odasi/logo-arsivi/ adresinden alındı

Türkoğlu, S. (2008). Görsel iletişim tasarımında kurumsal kimlik ve "İstanbul Üniversitesi” örneği. Yüksek Lisans Tezi. İstanbul: İstanbul Üniversitesi Sosyal Bilimler Enstitüsü.

Van Riel, C. B., \& Balmer, J. M. (1997). Corporte identity: the concept, its measurement and management. Europan Journal of Marketing, 31 (5/6), 340-355.

Yıldırım, A., \& Şimşek, H. (2006). Sosyal bilimlerde nitel araştırma yöntemleri. Ankara: Seçkin Yayıncılık.

Zengin, F. (2016). Dijitalleşmenin Türk sinemasında yarattığı dönüşüm: üretim, dağıtım ve gösterim. Doktora Tezi. İstanbul: İstanbul Üniversitesi Sosyal Bilimler Enstitüsü. 


\title{
Examining Turkish Production Companies in the Context of Visual Identity: The Example of BKM
}

\author{
Mesut Aytekin (Asst. Prof. Dr.) \\ Özer Silsüpür (Lect. Ph.D.)
}

\section{Extended Abstract}

Corporate identity is the visual and non-visual works of institutions that describe how they differentiate in the eyes of their target audiences and how they position themselves against their competitors (Silsüpür, 2015). The visual identity, which enables institutions to differentiate from each other with combination of visual elements, reflects the design works of institution to the target audiences (Bayçu, 2012a) and helps the institution to introduce itself and draw the attention of the target audiences to the institution (Bouchet, 2000). For this reason, institutions attach importance to visual identity studies in order to be known by the target audience and to create a corporate image (Türkoğlu, 2008) and in visual identity studies in order to achieve their corporate goals, to differentiate from their competitors, to influence target audiences and to have a positive place in target audience perceptions.

Visual identity, defined as institutions expressing themselves visually (Bakan, 2011); It includes the spelling of the name of the institution, the color, the font and the design of the symbols used in all kinds of tools and equipment belonging to the institution (Peltekoğlu, 2004). Considering the impressiveness and attractiveness of the visual, institutions should use elements such as color, shape, font, and typography in their logo design, and they should design their logos with visual identity components suitable for the structure and personality of the institution.

Based on the literature, answers to the following questions were sought in the study.

1. What are the formal features of the production company logo?

2. What is the typography of the production company logo?

3. What colors are used in the production company logo?

4. Why were the colors in the production company logo chosen?

5. What are the features of the production company logo?

6. Are there alternative designs of the production company logo?

7. Is there information about the production company logo on the website?

8. Does the production company use its logo in all its channels in accordance with its original design?

9. Can the production company logo represent the brand?

10. Does the production company logo match the visual identity and complete the visual identity?

This research examines the logos of production companies operating in Turkish Cinema, an important element of visual identity. The meaning of the BKM logo, which was chosen as a sample, what kind of indicators it contains, and the messages it wants to give were analyzed in detail between 01.05 .2021 and 15.05 .2021 by content analysis method.

In DergiPark and YÖK Thesis Center, no articles and theses were found on the key concepts of "logo", "cinema" and "Turkish Cinema". Although there are studies on the 
logos of different brands in many sectors in the literature, it has been determined, there is no study on the cinema industry, especially about production companies. The research is one of the first researches in terms of the subject of study and is of great importance for subsequent studies. Research makes a current contribution to the literature and provides data that can be evaluated within the corporate identity studies of many companies operating at different stages of the Turkish Cinema value.

The categorization (Logo Font, Logo Line, Color, Limitation) reconstructed in line with the conceptual framework was used by making use of the categorization designed by Özlem Topçu (2017) for her study titled "The Effect of a Logo on a Brand in Creating Corporate Identity".

The corporate logo of BKM was examined between 01.05.2021 and 15.05.2021.It was examined to the extent elements of visual identity were taken into account and whether the designs of visual identity were considered as a whole. The following results were obtained in the study:

BKMhas produced the most films in Turkey in recent years and is the leading company in terms of audience and revenue, and draws attention with its corporate structure. BKM operates in different cultural and artistic fields such as theatre, television, concert and cinema. Visual identity work, which is one of the important elements of corporate identity of BKM has signed many national and international projects, was examined under the logo subheading, and it was seen that BKM created and used its logo with a professional approach.

BKM's last logo, which has used two logos since its establishment, consists of the initials of the institution's name. The logo has positioned itself differently from other production company logos with the arrangement of its letters, its size, and the chosen font. The choice of color to form a whole with the typography has also made the logo more prominent. Main color magenta has strengthened Logo due to positive emotions and associations it carries, adding a value to the brand.BKM logo has a design that complements the visual identity, highlights the brand and can represent it everywhere.

In addition to memorability, easy-to-read and perceptible structure, the BKM logo, which has alternative ready-made designs according to the ground and suitable for different projects, has prevented the graphical problems that may be encountered beforehand. Ready-made designs are available on the website so that everyone can access them.

In terms of typography, use of color and application areas gives the impression of a logo that has been thought through and professional work has been carried out. It has a balanced and holistic design. The logo has been successfully applied in the social media accounts of the production company, drawing attention to its printed content, dimensions, colors and features. These applications both in the social media accounts of the institution, in the movie posters, in the press kits and in the websites.

Complementing the corporate identity, bringing the visual identity to the forefront and adding value to the brand in terms of awareness, recognition and retention, the BKM logo draws attention as a corporate identity material that Turkish production companies should take as an example in their visual identity studies. Logo offerssolutions for 
production companies that have problems in terms of institutionalization and visual representation in Turkish Cinema.

Keywords: Communication, Turkish Cinema, Production Companies, Visual Identity, Logo, BKM.

Bu makale intihal tespit yazııımlarıyla taranmıştır. Intihal tespit edilmemiştir.

This article has been scanned by plagiarism detection softwares. No plagiarism detected.

Bu çalışmada "Yükseköğretim Kurumları Bilimsel Araştırma ve Yayın Etiği Yönergesi” kapsamında uyulması belirtilen kurallara uyulmuştur.

In this study, the rules stated in the "Higher Education Institutions Scientific Research and Publication Ethics Directive" were followed.

Yazarların çalışmadaki katkı oranları eşittir.

The authors' contribution rates in the study are equal.

Çalışma kapsamında herhangi bir kurum veya kişi ile çıkar çatışması bulunmamaktadır.

There is no conflict of interest with any institution or person within the scope of the study. 